\title{
Effects of Farmyard Manure and Inorganic Fertilizer Application on Soil Physico-Chemical Properties and Nutrient Balance in Rain-Fed Lowland Rice Ecosystem
}

\author{
Tilahun Tadesse $^{1 *}$, Nigussie Dechassa ${ }^{2}$, Wondimu Bayu $^{3}$, Setegn Gebeyehu ${ }^{4}$ \\ ${ }^{1}$ Amhra Region Agricultural Research Institute, Ethiopia; ${ }^{2}$ Haramaya University, Ethiopia; ${ }^{3}$ ICARDA, Ethiopia; ${ }^{4}$ Ethiopian Institute \\ of Agricultural Research, Ethiopia. \\ Email: *tilahuntade@yahoo.com
}

Received November $15^{\text {th }}, 2012$; revised December $17^{\text {th }}, 2012$; accepted December $25^{\text {th }}, 2012$

\begin{abstract}
A field experiment was conducted to assess the effects of combined application of farm yard manure (FYM) and inorganic NP fertilizers on soil physico-chemical properties and nutrient balance in a rain-fed lowland rice production system in Fogera plain, northwestern Ethiopia. The study was carried out during the main cropping seasons of 2010 and 2011. Twenty-seven treatments comprising a factorial combination of three rates of FYM $\left(0,7.5\right.$, and $\left.15 \mathrm{t}^{-h^{-1}}\right)$, three rates of nitrogen $\left(0,60,120 \mathrm{~kg} \cdot \mathrm{N} \cdot \mathrm{ha}^{-1}\right)$ and three rates of phosphorus $\left(0,50\right.$ and $\left.100 \mathrm{~kg} \cdot \mathrm{P}_{2} \mathrm{O}_{5} \cdot \mathrm{ha}^{-1}\right)$ were tested. The experiments were laid out as a randomized complete block design with three replications. Bulk density, organic matter content, and available water holding capacity, total $\mathrm{N}$, and available $\mathrm{P}$ of the soil were measured just after harvesting the rice crop. Results showed that application of $15 \mathrm{t} \cdot \mathrm{FYM} \cdot \mathrm{ha}^{-1}$ significantly increased soil organic matter and available water holding capacity but decreased the soil bulk density, creating a good soil condition for enhanced growth of the rice crop. Application of $15 \mathrm{tFYM} \cdot \mathrm{ha}^{-1}$ increased the level of soil total nitrogen from $0.203 \%$ to $0.349 \%$. Combined application of $15 \mathrm{t} \cdot \mathrm{ha}^{-1} \cdot \mathrm{FYM}$ and $100 \mathrm{~kg} \cdot \mathrm{P}_{2} \mathrm{O}_{5} \cdot \mathrm{ha}^{-1}$ increased the available phosphorous from $11.9 \mathrm{ppm}$ to $38.1 \mathrm{ppm}$. Positive balances of soil $\mathrm{N}$ and $\mathrm{P}$ resulted from combined application of FYM and inorganic $\mathrm{N}$ and P sources. Application of $15 \cdot \mathrm{t} \mathrm{ha}^{-1} \cdot \mathrm{FYM}$ and $120 \mathrm{~kg} \cdot \mathrm{N} \cdot \mathrm{ha}^{-1}$ resulted in $214.8 \mathrm{~kg} \cdot \mathrm{ha}^{-1} \cdot \mathrm{N}$ positive balance while application of 15 $\mathrm{t} \cdot \mathrm{ha} \mathrm{a}^{-1} \cdot \mathrm{FYM}$ and $100 \mathrm{~kg} \cdot \mathrm{P}_{2} \mathrm{O}_{5} \cdot \mathrm{ha}^{-1}$ resulted in a positive balance of $69.3 \mathrm{~kg} \cdot \mathrm{P}_{2} \mathrm{O}_{5} \cdot \mathrm{ha}^{-1}$ available P. From the results of this experiment, it could be concluded that combined application of FYM and inorganic $\mathrm{N}$ and $\mathrm{P}$ fertilizers improved the chemical and physical properties, which may lead to enhanced and sustainable production of rice in the study area.
\end{abstract}

Keywords: FYM; Nitrogen; Phosphorous; Nutrient Balance; Rain-Fed Rice

\section{Introduction}

Despite the past gains in rice production through chemical fertilizers, recent observations of stagnant or declining yields have raised concerns about the long-term sustainability of the crop production [1]. Continuous use of inorganic fertilizers leads to deterioration in soil chemical, physical, and biological properties, and soil health [2]. The negative impacts of chemical fertilizers, coupled with escalating prices, have led to growing interests in the use of organic fertilizers as a source of nutrients $[2$, 3]. Organic materials such as FYM have traditionally been used by rice farmers [3]. FYM supplies all major nutrients $(\mathrm{N}, \mathrm{P}, \mathrm{K}, \mathrm{Ca}, \mathrm{Mg}, \mathrm{S}$, ) necessary for plant growth, as well as micronutrients $(\mathrm{Fe}, \mathrm{Mn}, \mathrm{Cu}$ and $\mathrm{Zn})$. Hence, it acts as a mixed fertilizer [1,4]. FYM improves soil physical, chemical and biological properties [1]. Im-

"Corresponding author. provement in the soil structure due to FYM application leads to a better environment for root development [5]. FYM also improves soil water holding capacity [4]. The fact that the use of organic fertilizers improves soil structure, nutrient exchange, and maintains soil health has raised interests in organic farming [1].

The use of FYM alone as a substitute to inorganic fertilizer is not be enough to maintain the present levels of crop productivity of high yielding varieties [6]. Therefore, integrated nutrient management in which both organic manures and inorganic fertilizers are used simultaneously is the most effective method to maintain a healthy and sustainably productive soil [4]. Emerging evidence indicated that integrated soil fertility management involving the judicious use of combined organic and inorganic resources is a feasible approach to overcome soil fertility constraints [6]. The high cost of making inorganic fertilizers accessible to farmers in Ethiopia, coupled with the 
availability of livestock in the country, necessitates the use of integrated nutrient management. However, this practice has not yet been tested in rain-fed lowland rice production in Ethiopia. The objective of this study was to assess the effects of combined applications of FYM and inorganic (NP) fertilizers on the soil physico-chemical properties and nutrient balance under the rain-fed lowland rice production system in Fogera plains, northwestern Ethiopia.

\section{Materials and Methods}

\subsection{Description of the Study Site}

Fogera plain is found in northwestern Ethiopia at $13^{\circ} 19^{\prime} \mathrm{N}$ latitude, $37^{\circ} 03^{\prime} \mathrm{E}$ longitude at an altitude of $1815 \mathrm{~m}$ above sea level. Eleven-year (2001-2011) meteorological data of the area indicates that, in the main cropping sea- son (June-October), the area has mean annual minimum and maximum temperatures of $13.5^{\circ} \mathrm{C}$ and $26.1^{\circ} \mathrm{C}$, respectively. Rainfall of the area is uni-modal, mainly falling from June to October, and amounts to $1205 \mathrm{~mm}$. The soil is vertisol with a clay content of $71.25 \%$. It is slightly acidic (pH 5.90) and the $20 \mathrm{~cm}$ soil horizon contains $0.22 \%$ total N, $12.64 \mathrm{ppm}$ available P (Olsen), $0.93 \mathrm{cmol}$ $(+)$ exchangeable $\mathrm{K} \cdot \mathrm{kg} \cdot \mathrm{soil}^{-1}, 3 \%$ organic carbon, and $52.9 \mathrm{cmol}(+) \mathrm{kg}^{-1}$ CEC. According to Bernard (1993) [7], the total $\mathrm{N}$ and available $\mathrm{P}$ contents of the soil are medium while the organic matter content is low. According to Roy et al. (2006) [8], the exchangeable potassium content and CEC are high.

\subsection{Materials used for the Experiment}

\subsubsection{Fertilizer Material}

Urea $(46 \% \mathrm{~N})$, Diammonimum phosphate (DAP) $(46 \%$ $\mathrm{P}_{2} \mathrm{O}_{5}$ and $\left.18 \% \mathrm{~N}\right)$, and TSP $\left(46 \% \mathrm{P}_{2} \mathrm{O}_{5}\right)$ were used as inorganic $\mathrm{N}$ and $\mathrm{P}$ sources. FYM was used as an organic fertilizer.

\subsubsection{Planting Material}

A rice variety called $\mathrm{X}$-Jigna was used as a test crop. The variety matures in 130 days (medium), has a medium plant height.

\subsection{Treatments and Experimental Design}

The study was conducted during the main cropping seasons of 2010 and 2011. Treatments consisted of three rates of FYM $\left(0,7.5\right.$, and $\left.15 \mathrm{t} \cdot \mathrm{ha}^{-1}\right)$, three rates of $\mathrm{N}$ fertilizer $\left(0,60,120 \mathrm{Kg} \cdot \mathrm{N} \cdot \mathrm{ha}^{-1}\right)$ and three rates of P fertileizer $\left(0,50,100 \mathrm{~kg} \cdot \mathrm{P}_{2} \mathrm{O}_{5} \cdot \mathrm{ha}^{-1}\right)$. The experiment was laid out in a randomized complete block design in a factorial arrangement and replicated three times per treatment. Gross and net plot sizes were $4 \mathrm{~m} \times 5 \mathrm{~m}$ and $3 \mathrm{~m} \times 4 \mathrm{~m}$, respectively.

\subsection{Experimental Procedures}

Sun-dried FYM collected from Andasa Livestock Research Center was applied on dry weight basis a month prior to planting and thoroughly mixed with the soil. N, P and $\mathrm{K}$ contents of the FYM used in the experiment and the relative $\mathrm{N}, \mathrm{P}$, and $\mathrm{K}$ additions to the soil were determined (Tables 1 and 2). All P and half of the N fertilizers for the respective inorganic $\mathrm{N}$ and $\mathrm{P}$ treatments were applied at planting. The remaining half of the inorganic $\mathrm{N}$ fertilizer was applied at tillering stage. Prior to planting, surface $(0-20 \mathrm{~cm})$ soil samples, from twelve spots across the experimental field, were collected in a zizag pattern, composited, and analyzed for soil physico-chemical properties following the procedure outlined by Page et al. (1982) [9].

The rice seed was broadcast by hand at the seed rate of $140 \mathrm{~kg} \cdot \mathrm{ha}^{-1}$. Weeds were removed manually three times (at early tillering, maximum tillering and booting stages). No insecticide or fungicide was applied as there was no serious incidence of insect pests or diseases. Harvesting was done manually using hand sickles.

\subsection{Data Collection and Measurements}

Just after harvesting the crop, composite surface (0 - 20 $\mathrm{cm})$ soil samples were collected from five spots for each plot for determination of total $\mathrm{N}$, available $\mathrm{P}$, bulk density, organic matter contents as well as the water contents of the soil at field capacity and permanent wilting point. Available water capacity (AWC) is defined as the water held between field capacity and the water content at permanent wilting point (PWP), and is the amount of water a soil can store that is available for use by plants [10]. The AWC therefore was calculated as using the following formula:

$$
\mathrm{AWC}=\mathrm{FC}-\theta \mathrm{PWP}
$$

where $\mathrm{FC}$ is the water content at field capacity and $\theta \mathrm{PWP}$ is the water content at the permanent wilting point [10].

Partial nutrient balances at plot level for each treatment were estimated by separating inputs and outputs of the plot. The main inputs were $\mathrm{N}$ and $\mathrm{P}$ from inorganic fertilizer and FYM. N and P nutrient uptakes by the rice plants were considered as output. The partial nutrient balance for $\mathrm{N}$ and $\mathrm{P}$ were calculated by subtracting nu-

Table 1. Organic matter (OM), N, P, and $\mathrm{K}$ composition of the FYM used in the experiment.

\begin{tabular}{ccccc}
\hline Year & OM $(\%)$ & $\mathrm{N}(\%)$ & $\mathrm{P}(\%)$ & $\mathrm{K}(\%)$ \\
\hline 2010 & 10.5 & 1.83 & 0.49 & 1.92 \\
2011 & 11.3 & 2.02 & 0.58 & 2.75 \\
\hline
\end{tabular}


trient uptake from the total nutrient added to the plots. Nutrient balance exercises may serve as an instrument to provide indicators for the sustainability of agriculture systems [11]. However, the nutrient balance did not account for the addition of nutrients from rainfall, dry deposition, biological nitrogen fixation, nor gaseous losses of $\mathrm{N}$, or weed uptake of nutrients from the soil [11]. Measurement of these inputs and output were beyond the scope of this study. Data collected were subjected to analysis of variance using SAS software [12]. Differences among treatment means were delineated using the least significant difference test at the alpha level of 0.05 .

\section{Results}

\subsection{Soil Total Nitrogen and Available Phosphorus}

Analysis of the soil test data revealed that total nitrogen and available phosphorus contents of the soil responded significantly to the main effect of FYM application (Table 3). The main effect of nitrogen, the interaction effect of nitrogen with any of the other fertilizers as well as the interaction effect of the three fertilizers did not affect total nitrogen or available phosphorus contents of the soil (Table 3). On the other hand, the available phosphorus content of the soil was significantly influenced by phosphorus application and by the interaction effect of FYM and phosphorus applications.

Increasing the rate of FYM from nil to 7.5 and $15 \mathrm{t} \cdot \mathrm{ha}^{-1}$ significantly increased the total nitrogen content of the soil by about $17 \%$ and $30 \%$, in the order mentioned here (Figure 1). The highest available soil phosphorus after rice harvest was realized with the combined application of $15 \mathrm{t} \cdot \mathrm{ha}^{-1} \mathrm{FYM}$ with 50 and $100 \mathrm{~kg} \cdot \mathrm{ha}^{-1} \mathrm{P}_{2} \mathrm{O}_{5}$ (Figure 2). The available phosphate content of the soil significantly increased in response to the interaction effect of FYM and phosphorus by about $9 \%$ (Figure 2).

\subsection{Soil Organic Matter, Bulk Density and Available Water Holding Capacity}

The soil organic matter content just after the rice harvest responded significantly to the application of FYM only, the highest organic matter being recorded for the highest $\left(15 \mathrm{t} \cdot \mathrm{ha}^{-1}\right)$ FYM application (Tables 4 and 5). Soil physical characteristics after rice harvesting such as soil bulk density and available water holding capacity showed significant response only to FYM application but not to the inorganic fertilizers and their interactions with FYM (Table 4). Compared to lower two rates, the $15 \mathrm{t} \cdot \mathrm{ha}^{-1} \mathrm{FYM}$ resulted in the lowest soil bulk density (Table 5). Concerning the soil available water holding capacity, statistically equivalent and higher values were recorded for 7.5 $\mathrm{t} \cdot \mathrm{ha}^{-1}$ and $15 \mathrm{t} \cdot \mathrm{ha}^{-1}$ FYM (Table 5). Application of 15 $\mathrm{t} \cdot \mathrm{ha} \mathrm{C}^{-1}$ FYM increased the soil organic matter and available water holding capacity by about $2.16 \%$ and $17.6 \%$, respectively, while it reduced the soil bulk density by $0.31 \mathrm{~g} \cdot \mathrm{cm}^{-3}$ (Table 5).

\subsection{Soil $N$ and $P$ Balances}

The Balance of soil nitrogen over all treatments revealed that much of nitrogen was removed from the soil with the application of inorganic $\mathrm{N}$ fertilizer or with no fertilizer application both resulting in negative soil $\mathrm{N}$ balance (Table 6). Regarding the balance of soil phosphorous, it was negative for the lower P levels $\left(0\right.$ and $\left.50 \mathrm{P} \cdot \mathrm{kg} \cdot \mathrm{ha}^{-1}\right)$ which resulted in negative soil $\mathrm{P}$ balance (Table 7). Combined application of both FYM and inorganic $\mathrm{N}$ and $\mathrm{P}$ sources mostly resulted in positive balance of soil $\mathrm{N}$ and P (Tables 6 and 7). The highest positive $\mathrm{N}$ balance was recorded for the combined application of 15 $\mathrm{t} \cdot \mathrm{FYM} \cdot \mathrm{ha}^{-1}$ and $120 \mathrm{~kg} \cdot \mathrm{N} \cdot \mathrm{ha}^{-1}$ with no inorganic phosphorus application (Table 6). Similarly, the highest positive $\mathrm{P}$ balance was realized with the combined application of $15 \mathrm{t} \cdot \mathrm{FYM} \cdot \mathrm{ha}^{-1}, 100 \mathrm{~kg} \cdot \mathrm{P}_{2} \mathrm{O}_{5} \cdot \mathrm{ha}^{-1}$ with no inorganic nitrogen application (Table 7).

\section{Discussion}

\subsection{Soil Total Nitrogen and Available Phosphorus}

The In Fogera plain, rice is generally produced with no addition of organic and inorganic fertilizers. Manure is currently collected and used for fuel rather than being used as fertilizer. Decline in soil fertility and rice yield have been markedly observed in Fogera plain. In the present investigation, it was found that the total soil nitrogen content after rice harvest increased significantly in response to the application of FYM. According to soil total nitrogen ratings of Hazeltonan and Murphy (2007) [13], FYM application raised the soil $\mathrm{N}$ to the highest

Table 2. OM, N, P, and K additions to the soil form the FYM.

\begin{tabular}{|c|c|c|c|c|c|c|c|c|}
\hline \multirow{2}{*}{ Year } & \multicolumn{4}{|c|}{$7.5 \mathrm{t} \cdot \mathrm{FYM} \cdot \mathrm{ha}^{-1}$} & \multicolumn{4}{|c|}{$15 \mathrm{t} \cdot \mathrm{FYM} \cdot \mathrm{ha}^{-1}$} \\
\hline & $\mathrm{OM}\left(\mathrm{kg} \cdot \mathrm{ha}^{-1}\right)$ & $\mathrm{N}\left(\mathrm{kg} \cdot \mathrm{ha}^{-1}\right)$ & $\mathrm{P}\left(\mathrm{kg} \cdot \mathrm{ha}^{-1}\right)$ & $\mathrm{K}\left(\mathrm{kg} \cdot \mathrm{ha}^{-1}\right)$ & $\begin{array}{c}\mathrm{OM} \\
\left(\mathrm{kg} \cdot \mathrm{ha}^{-1}\right)\end{array}$ & $\mathrm{N}\left(\mathrm{kg} \cdot \mathrm{ha}^{-1}\right)$ & $\mathrm{P}\left(\mathrm{kg} \cdot \mathrm{ha}^{-1}\right)$ & $\mathrm{K}\left(\mathrm{kg} \cdot \mathrm{ha}^{-1}\right)$ \\
\hline 2010 & 787.5 & 137.3 & 36.8 & 144.0 & 1575.0 & 274.5 & 73.5 & 288.0 \\
\hline 2011 & 847.5 & 151.5 & 43.5 & 206.3 & 1695.0 & 303.0 & 87.0 & 412.5 \\
\hline
\end{tabular}


Table 3. Mean squares of soil total $N$ and available $P$ after rice harvest due to integrated use of FYM, $N$ and $P$ in rainfed lowland rice grown at Fogera in 2010 and 2011.

\begin{tabular}{ccc}
\hline Source of variation & Soil total $\mathrm{N}$ & Available Soil P \\
\hline FYM & $0.143^{*}$ & $34.95^{*}$ \\
$\mathrm{~N}$ & $0.031 \mathrm{NS}$ & $9.035 \mathrm{NS}$ \\
$\mathrm{P}$ & $0.002 \mathrm{NS}$ & $18.939^{*}$ \\
$\mathrm{FYM} \times \mathrm{N}$ & $0.006 \mathrm{NS}$ & $1.987 \mathrm{NS}$ \\
$\mathrm{FYM} \times \mathrm{P}$ & $0.001 \mathrm{NS}$ & $21.023^{*}$ \\
$\mathrm{~N} \times \mathrm{P}$ & $0.011 \mathrm{NS}$ & $1.776 \mathrm{NS}$ \\
$\mathrm{FYM} \times \mathrm{N} \times \mathrm{P}$ & $0.003 \mathrm{NS}$ & $2.453 \mathrm{NS}$ \\
$\mathrm{EMS}$ & 0.012 & 4.776 \\
\hline
\end{tabular}

*and NS denote significant difference and nonsignificant difference at $\mathrm{P} \leq$ 0.05 , respectively.

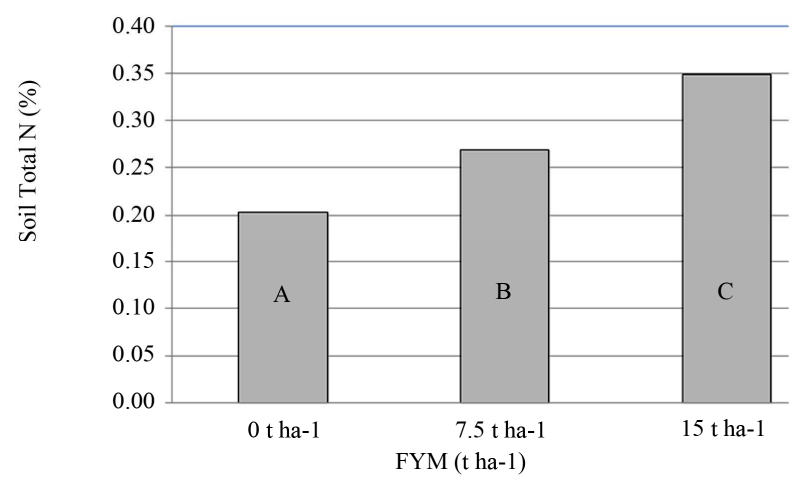

Figure 1. Effect of FYMon soil total N (\%) after harvest in rainfed rice at Fogera, northwestern Ethiopia.

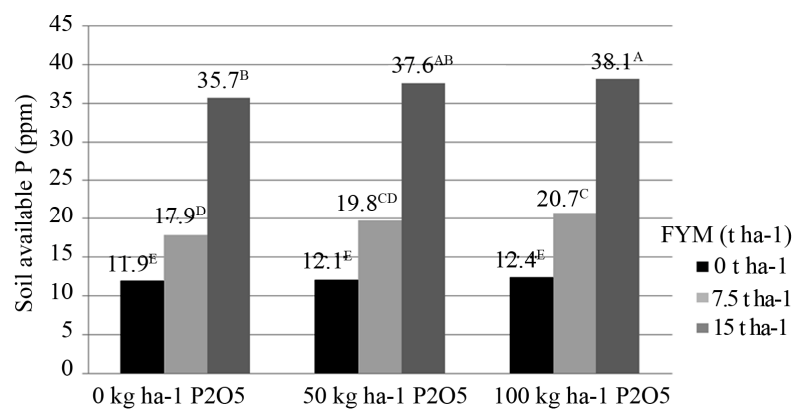

Figure 2. Effect of integrated FYM and phosphorous application on soil available P (ppm) at Fogera in 2010 and 2011.

rate. On the other hand, the highest available soil phosphorus after rice harvest was realized with the combined application of $15 \mathrm{t} \cdot \mathrm{ha}^{-1} \mathrm{FYM}$ and $100 \mathrm{~kg} \cdot \mathrm{ha}^{-1} \mathrm{P}_{2} \mathrm{O}_{5}$. These results are in conformity with the finding of Thamaraiselvi et al. (2012) [14] who reported increases in soil total $\mathrm{N}$ and available phosphorus due to FYM application. Similarly, Aziz et al. (2010) [15] reported maximum soil $\mathrm{N}$ and $\mathrm{P}$ contents after a maize harvest for FYM whereas the minimum $\mathrm{N}$ and $\mathrm{P}$ contents were
Table 4. Mean squares of organic matter, bulk density, and available water holding capacity of soil due to integrated use of FYM, $N$ and $P$ in rain-fed lowland rice grown at Fogera in 2010 and 2011.

\begin{tabular}{cccc}
\hline $\begin{array}{c}\text { Source of } \\
\text { variation }\end{array}$ & $\begin{array}{c}\text { Organic } \\
\text { matter }\end{array}$ & $\begin{array}{c}\text { Soil bulk } \\
\text { density }\end{array}$ & $\begin{array}{c}\text { Available water holding } \\
\text { capacity of soil }\end{array}$ \\
\hline FYM & $31.841^{*}$ & $0.487^{*}$ & $2332.168^{*}$ \\
$\mathrm{~N}$ & $1.266 \mathrm{NS}$ & $0.002 \mathrm{NS}$ & $24.78 \mathrm{NS}$ \\
$\mathrm{P}$ & $0.477 \mathrm{NS}$ & $0.004 \mathrm{NS}$ & $4.121 \mathrm{NS}$ \\
$\mathrm{FYM} \times \mathrm{N}$ & $1.199 \mathrm{NS}$ & $0.003 \mathrm{NS}$ & $9.402 \mathrm{NS}$ \\
$\mathrm{FYM} \times \mathrm{P}$ & $0.315 \mathrm{NS}$ & $0.001 \mathrm{NS}$ & $10.181 \mathrm{NS}$ \\
$\mathrm{N} \times \mathrm{P}$ & $0.137 \mathrm{NS}$ & $0.002 \mathrm{NS}$ & $3.917 \mathrm{NS}$ \\
$\mathrm{FYM} \times \mathrm{N} \times \mathrm{P}$ & $0.229 \mathrm{NS}$ & $0.001 \mathrm{NS}$ & $9.035 \mathrm{NS}$ \\
$\mathrm{EMS}$ & 2.090 & 0.007 & 47.53 \\
\hline
\end{tabular}

"and NS denote significant difference and nonsignificant difference at $\mathrm{P} \leq$ 0.05 , respectively.

Table 5. The interaction effect of integrated FYM, N, and $P$ application on bulk density $\left(\mathrm{g} \cdot \mathrm{cm}^{-3}\right)$, organic matter content (\%) and available water holding capacity of soil just after rice harvesting at Fogera in 2010 and 2011

\begin{tabular}{cccc}
\hline FYM & $\begin{array}{c}\text { Organic matter } \\
(\%)\end{array}$ & Bulk density & $\begin{array}{c}\text { Available water holding } \\
\text { capacity }\end{array}$ \\
\hline $0 \mathrm{t} \cdot \mathrm{ha}^{-1}$ & $3.26^{\mathrm{B}}$ & $1.33^{\mathrm{A}}$ & $47.4^{\mathrm{B}}$ \\
$7.5 \mathrm{t} \cdot \mathrm{ha}^{-1}$ & $3.84^{\mathrm{B}}$ & $1.13^{\mathrm{B}}$ & $49.1^{\mathrm{AB}}$ \\
$15 \mathrm{t} \cdot \mathrm{ha}^{-1}$ & $4.78^{\mathrm{A}}$ & $1.02^{\mathrm{B}}$ & $52.3^{\mathrm{A}}$ \\
$\mathrm{CV}(\%)$ & 18.23 & 17.55 & $28.67 \mathrm{LSC}$ \\
\hline
\end{tabular}

Means followed by the same letters within each growth parameter are not different at $\mathrm{P} \leq 0.05$.

found for the treatments with the application of inorganic NPK fertilizer. The increase in soil N and P after FYM application might be due to the direct addition of $\mathrm{N}$ and $\mathrm{P}$ through decomposition of the FYM added to the soil. The improvement in the soil available P with FYM addition could be attributed to many factors, such as the addition of P through FYM, and retardation of soil P fixation by organic anions formed during FYM decomposition [16]. Many authors associated the soil nutrient improvement role of FYM to a residual effect on succeeding crops. Bodruzzaman et al. (2010) [17] stated that FYM application on a preceding rice crop had a residual effect on the yield of a succeeding wheat crop. Thus, improvements in soil $\mathrm{N}$ and P nutrient status due to FYM application could sustain high rice crop yields ensuring longterm sustainability of the system.

\subsection{Soil Organic Matter, Bulk Density, and Available Water Holding Capacity}

Given to the low organic matter content of the soil, the rice production field of Fogera plain has low available 
water holding capacity. The negative impacts of the repeatedly occurring terminal moisture stress are more pronounced because of the low water holding capacity of the soil. On top of supplying plants with nutrients, FYM has several advantages in improving the soil organic matter, water holding capacity, and bulk density $[1,4]$. In the current investigation, application of FYM significantly increased soil organic matter and available water holding capacity but decreased the soil bulk density. Compared to no FYM application, 7.5 and $15 \mathrm{t} \cdot \mathrm{ha}^{-1} \cdot \mathrm{FYM}$ applications resulted in $3.6 \%$ and $10.3 \%$ increases in available water holding capacity, $17.8 \%$ and $46.6 \%$ increases in $\mathrm{OM}$, and $23.3 \%$ and $15.0 \%$ decreases in $\mathrm{BD}$, respectively. The increased water holding capacity of the soil may enable the rice crop in Fogera plain to withstand occurrence of terminal moisture stress and give better yields. In agreement with the results of this study, Shirani et al. (2002) [18] reported significantly increased soil organic matter and decreased soil bulk density just after harvesting a maize field supplied with FYM. Bayu et al. (2006) [19] also concluded that FYM application increased soil organic carbon content by up to $67 \%$ over the control treatment. The present observation of improved soil water holding capacity with FYM application is supported by the results of Dejene and Lemlem (2012) [4]. A similar experiment on sorghum crop in the northeastern part of the country demonstrated that the soil water content was significantly improved with FYM application and plots that received 10 and $15 \mathrm{t} \cdot \mathrm{FYM} \cdot \mathrm{ha}^{-1}$ had $1.3 \%$ and $3.5 \%$ greater water content than the control

Table 6. The interaction effect of integrated FYM, N, and $P$ application on soil $\mathbf{N}$ balance at Fogera in 2010.

\begin{tabular}{|c|c|c|c|c|c|}
\hline Fertilizer combination (FYM & $\begin{array}{l}\mathrm{N} \text { in the inorganic fertilizer } \\
\left(\mathrm{kg} \cdot \mathrm{ha}^{-1}\right)\end{array}$ & $\mathrm{N}$ in FYM $\left(\mathrm{kg} \cdot \mathrm{ha}^{-1}\right)$ & $\begin{array}{l}\text { Total } \mathrm{N} \text { added } \\
\left(\mathrm{kg} \cdot \mathrm{ha}^{-1}\right)\end{array}$ & $\begin{array}{l}\text { Nitrogen uptake } \\
\left(\mathrm{kg} \cdot \mathrm{ha}^{-1}\right)\end{array}$ & $\begin{array}{l}\mathrm{N} \text { balance } \\
\left(\mathrm{kg} \cdot \mathrm{ha}^{-1}\right)\end{array}$ \\
\hline & (1) & (2) & $(3)=(1)+(2)$ & (4) & $(5)=(3)-(4)$ \\
\hline $0-0-0$ & 0 & 0 & 0 & 81.6 & -81.6 \\
\hline $0-0-50$ & 0 & 0 & 0 & 79.4 & -79.4 \\
\hline $0-0-100$ & 0 & 0 & 0 & 91.8 & -91.8 \\
\hline $0-60-0$ & 60 & 0 & 60 & 93.4 & -33.4 \\
\hline $0-60-50$ & 60 & 0 & 60 & 95.6 & -35.6 \\
\hline $0-60-100$ & 60 & 0 & 60 & 112.2 & -52.2 \\
\hline $0-120-0$ & 120 & 0 & 120 & 122.2 & -2.2 \\
\hline $0-120-50$ & 120 & 0 & 120 & 145.5 & -25.5 \\
\hline $0-120-100$ & 120 & 0 & 120 & 125.1 & -5.1 \\
\hline $7.5-0-0$ & 0 & 144.4 & 144.4 & 122.6 & 21.8 \\
\hline $7.5-0-50$ & 0 & 144.4 & 144.4 & 114.7 & 29.7 \\
\hline $7.5-0-100$ & 0 & 144.4 & 144.4 & 110.1 & 34.3 \\
\hline $7.5-60-0$ & 60 & 144.4 & 204.4 & 149.1 & 55.3 \\
\hline $7.5-60-50$ & 60 & 144.4 & 204.4 & 161.9 & 42.5 \\
\hline $7.5-60-100$ & 60 & 144.4 & 204.4 & 161.5 & 42.9 \\
\hline $7.5-120-0$ & 120 & 144.4 & 264.4 & 162.0 & 102.4 \\
\hline $7.5-120-50$ & 120 & 144.4 & 264.4 & 197.2 & 67.3 \\
\hline $7.5-120-100$ & 120 & 144.4 & 264.4 & 198.0 & 66.4 \\
\hline $15-0-0$ & 0 & 288.8 & 288.8 & 138.7 & 150.1 \\
\hline $15-0-50$ & 0 & 288.8 & 288.8 & 135.0 & 153.8 \\
\hline $15-0-100$ & 0 & 288.8 & 288.8 & 136.1 & 152.7 \\
\hline $15-60-0$ & 60 & 288.8 & 348.8 & 181.7 & 167.1 \\
\hline $15-60-50$ & 60 & 288.8 & 348.8 & 193.3 & 155.5 \\
\hline $15-60-100$ & 60 & 288.8 & 348.8 & 246.6 & 102.2 \\
\hline $15-120-0$ & 120 & 288.8 & 408.8 & 194.0 & 214.8 \\
\hline $15-120-50$ & 120 & 288.8 & 408.8 & 225.1 & 183.7 \\
\hline $15-120-100$ & 120 & 288.8 & 408.8 & 272.6 & 136.2 \\
\hline
\end{tabular}


Table 7. The interaction effect of integrated FYM, N, and $P$ application on soil $P$ balance at Fogera in 2010.

\begin{tabular}{|c|c|c|c|c|c|}
\hline \multirow{2}{*}{$\begin{array}{l}\text { Fertilizer combination (FYM } \\
\left.\mathrm{t} \cdot \mathrm{ha}^{-1}-\mathrm{N} \cdot \mathrm{Kg} \cdot \mathrm{ha}^{-1}-\mathrm{P}_{2} \mathrm{O}_{5} \cdot \mathrm{Kg} \cdot \mathrm{ha}^{-1}\right)\end{array}$} & $\begin{array}{l}\mathrm{P} \text { in the inorganic fertilizer } \\
\qquad\left(\mathrm{kg} \cdot \mathrm{ha}^{-1}\right)\end{array}$ & $\begin{array}{l}\text { P in FYM } \\
\left(\mathrm{kg} \cdot \mathrm{ha}^{-1}\right)\end{array}$ & $\begin{array}{l}\text { Total } \mathrm{P} \text { added } \\
\left(\mathrm{kg} \cdot \mathrm{ha}^{-1}\right)\end{array}$ & $\begin{array}{l}\text { P uptake } \\
\left(\mathrm{kg} \cdot \mathrm{ha}^{-1}\right)\end{array}$ & P balance $\left(\mathrm{kg} \cdot \mathrm{ha}^{-1}\right)$ \\
\hline & (1) & (2) & $(3)=(1)+(2)$ & (4) & $(5)=(3)-(2)$ \\
\hline $0-0-0$ & 0 & 0 & 0 & 26.5 & -26.5 \\
\hline $0-0-50$ & 21.8 & 0 & 21.8 & 28.4 & -6.6 \\
\hline $0-0-100$ & 43.7 & 0 & 43.7 & 35.4 & 8.3 \\
\hline $0-60-0$ & 0 & 0 & 0 & 28.0 & -28 \\
\hline $0-60-50$ & 21.8 & 0 & 21.8 & 30.6 & -8.8 \\
\hline $0-60-100$ & 43.7 & 0 & 43.7 & 43.4 & 0.3 \\
\hline $0-120-0$ & 0 & 0 & 0 & 33.8 & -33.8 \\
\hline $0-120-50$ & 21.8 & 0 & 21.8 & 40.8 & -19 \\
\hline $0-120-100$ & 43.7 & 0 & 43.7 & 40.8 & 2.9 \\
\hline $7.5-0-0$ & 0 & 40.2 & 40.2 & 33.1 & 7.1 \\
\hline $7.5-0-50$ & 21.8 & 40.2 & 62.0 & 42.6 & 19.4 \\
\hline $7.5-0-100$ & 43.7 & 40.2 & 83.8 & 39.7 & 44.1 \\
\hline $7.5-60-0$ & 0 & 40.2 & 40.2 & 36.0 & 4.2 \\
\hline $7.5-60-50$ & 21.8 & 40.2 & 62.0 & 46.9 & 15.1 \\
\hline $7.5-60-100$ & 43.7 & 40.2 & 83.8 & 50.3 & 33.5 \\
\hline $7.5-120-0$ & 0 & 40.2 & 40.2 & 43.4 & -3.2 \\
\hline $7.5-120-50$ & 21.8 & 40.2 & 62.0 & 52.2 & 9.8 \\
\hline $7.5-120-100$ & 43.7 & 40.2 & 83.8 & 60.0 & 23.8 \\
\hline $15-0-0$ & 0 & 80.3 & 80.3 & 45.4 & 34.9 \\
\hline $15-0-50$ & 21.8 & 80.3 & 102.1 & 48.5 & 53.6 \\
\hline $15-0-100$ & 43.7 & 80.3 & 123.9 & 54.6 & 69.3 \\
\hline $15-60-0$ & 0 & 80.3 & 80.3 & 50.6 & 29.7 \\
\hline $15-60-50$ & 21.8 & 80.3 & 102.1 & 62.5 & 39.6 \\
\hline $15-60-100$ & 43.7 & 80.3 & 123.9 & 81.7 & 42.2 \\
\hline $15-120-0$ & 0 & 80.3 & 80.3 & 44.4 & 35.9 \\
\hline $15-120-50$ & 21.8 & 80.3 & 102.1 & 62.6 & 39.5 \\
\hline $15-120-100$ & 43.7 & 80.3 & 123.9 & 80.6 & 43.3 \\
\hline
\end{tabular}

[19]. In the present investigation, application of inorganic $\mathrm{N}$ and $\mathrm{P}$ fertilizers were found to have no effect on soil organic matter, bulk density, and available water holding capacity. In line with the present result, Prasad and Sinha (2000) [5] and Khan et al. (2010) [1] reported nonsignificant effect of inorganic fertilizers on soil organic matter, bulk density, and available water holding capacity. Bayu et al. (2006) [19] also reported that application of inorganic fertilizers had no significant effect on the organic carbon content and bulk density of the soil.

The improvement in water holding capacity in response to the addition of organic matter is due to improved soil structure and water stable aggregates, as well as moisture retention capacity by increasing the total number of storage pores [20]. Improvement in soil aggregation is attributed to the action of polysaccharides and fulvic acid components of organic matter [5]. In FYM applied soils, water infiltrates easily, similar to forest soils [21]. The consequence of increased water infiltration combined with a higher organic matter content is increased soil water storage [21]. Especially in the topsoil, where the organic matter content is greater, more water can be stored [21]. Organic matter not only increases the water holding capacity of the soil but also increases the available water for plant growth [1]. In this way, water becomes available to rice plants for a longer duration [22].

\subsection{Soil $N$ and $P$ Balances}

The soil $\mathrm{N}$ nutrient balance in the present study revealed that much of the nitrogen was removed from the soil with 
the application of inorganic $\mathrm{N}$ fertilizer or with no fertilizer application both resulting in a negative soil $\mathrm{N}$ balance. Combined application of both FYM and inorganic $\mathrm{N}$ and $\mathrm{P}$ sources mostly resulted in a positive balance of soil $\mathrm{N}$ and $\mathrm{P}$ nutrients. The highest positive $\mathrm{N}$ balance was recorded for the combined application of $15 \mathrm{t} \cdot \mathrm{ha}^{-1}$ FYM, $120 \mathrm{~kg} \cdot \mathrm{ha}^{-1} \mathrm{~N}$ with no inorganic phosphorus application. The observed highest $\mathrm{N}$ balance was just due to the higher amount of $\mathrm{N}$ application, coupled with the lower uptake of the nutrient by the plant, compared to the treatments where the specified FYM-P combination was integrated with 50 and $100 \mathrm{~kg} \cdot \mathrm{ha}^{-1} \mathrm{P}_{2} \mathrm{O}_{5}$. Similarly, the highest positive $\mathrm{P}$ balance was realized with the combined application of $15 \mathrm{t} \cdot \mathrm{ha}^{-1} \mathrm{FYM}, 100 \mathrm{~kg} \cdot \mathrm{ha}^{-1} \mathrm{P}_{2} \mathrm{O}_{5}$ with no inorganic nitrogen application. In line with the present finding, Hossain, et al. (2010) [23] indicated that $\mathrm{N}$ and $\mathrm{P}$ replenishment through FYM with chemical fertilizer was enough to balance $\mathrm{N}$ and $\mathrm{P}$ removal by rice and the $\mathrm{N}$ and $\mathrm{P}$ balance was positive. Tiwari et al. (2010) [11] also reported similar findings that $\mathrm{N}$ and $\mathrm{P}$ balances were negative when inorganic fertilizers were applied and observe a positive balance of $\mathrm{N}$ and $\mathrm{P}$ nutrients due to application of FYM.

\section{Conclusion}

Farm yard manure has been receiving much attention because of its ability to sustain soil health in terms of fertility. In the current experiment, integrated use of farm yard manure and inorganic fertilizers was found to improve the soil total $\mathrm{N}$ and available $\mathrm{P}$. Moreover, the use of FYM significantly increased soil organic matter and available water holding capacity but decreased the soil bulk density, creating a good environment for growth and development of the rice crop. With the combined applications of FYM and inorganic N and P fertilizers, the soil $\mathrm{N}$ and $\mathrm{P}$ nutrient balances after the rice harvest were found to be in a good status. Generally, soil productivity and health may be more sustainable with the integrated application of farmyard manure and inorganic fertilizers than with the use of inorganic fertilizers alone. From the results of the current experiment, it could be concluded that combined applications of $15 \mathrm{t} \cdot \mathrm{ha}^{-1}$ FYM, 120 $\mathrm{kg} \cdot \mathrm{ha}^{-1} \cdot \mathrm{N}$ and $100 \mathrm{~kg} \cdot \mathrm{ha}^{-1} \cdot \mathrm{P}_{2} \mathrm{O}_{5}$ resulted in improvement of most soil physico-chemical properties and nutrient balances that may lead to increased and sustained production of rain-fed rice in Fogera plains of northwestern Ethiopia.

\section{REFERENCES}

[1] N. I. Khan, A. U. Malik, F. Umer and M. I. Bodla, "Effect of Tillage and Farm Yard Manure on Physical Properties of Soil," International Research Journal of Plant
Science, Vol. 1, No. 4, 2010, pp. 75-82.

[2] A. Mahajan, R. M. Bhagat and R. D. Gupta, "Integrated Nutrient Management in Sustainable Rice-Wheat Cropping System for Food Security in India," SAARC Journal of Agriculture, Vol. 6, No. 2, 2008, pp. 29-32.

[3] V. Satyanarayana, P. V. Prasad, V. R. K. Murthy and K. J. Boote, "Influence of Integrated Use of Farmyard Manure and Inorganic Fertilizers on Yield and Yield Components of Irrigated Lowland Rice," Journal of Plant Nutrition, Vol. 25, No. 10, 2002, pp. 2081-2090. doi:10.1081/PLN-120014062

[4] M. Dejene and M. Lemlem, "Integrated Agronomic Crop Managements to Improve Tef Productivity under Terminal Drought," In: I. Md. M. Rahman and H. Hasegawa, Eds., Water Stress, InTech Open Science, 2012, pp. 235254.

[5] B. Prasad and S. K. Sinha, "Long-Term Effects of Fertilizers and Organic Manures on Crop Yields, Nutrient Balance, and Soil Properties in Rice-Wheat Cropping System in Bihar," In: I. P. Abrol, K. F. Bronson, J. M. Duxbury and R. K. Gupta, Eds., Long-Term Soil Fertility Experiments in Rice-Wheat Cropping Systems. Rice-Wheat Consortium Paper Series 6, Rice-Wheat Consortium for the Indo-Gangetic Plains, New Delhi, 2000, pp. 105-119.

[6] A. Efthimiadou, D. Bilalis, A. Karkanis and B. FroudWilliams, "Combined Organic/Inorganic Fertilization Enhances Soil Quality and Increased Yield, Photosynthesis and Sustainability of Sweet Maize Crop," Australian Journal of Crop Science, Vol. 4, No. 9, 2010, pp. 722-729.

[7] P. K. Bernard, "Evaluation and Interpretation of Soil Analytical Data," National Soil Service Project, FAO/ UNDP/ETH/87/010, Ministry of Agriculture, Addis Ababa, 1993.

[8] R. N. Roy, A. Finck, G. J. Blair and H. L. S. Tandon, "Plant Nutrition for Food Security. A Guide for Integrated Nutrient Management," In: FAO, Ed., Fertilizer and Plant Nutrition Bulletin 16. Food and Agricultural Organization of United Nations, Rome, 2006, p. 348.

[9] A. L. Page, R. H. Miller and D. R. Keeney, "Methods of Soil Analysis. Part 2. Chemical and Microbiological Properties," 2nd Edition, Soil Science Society of America, Madison, 1982.

[10] K. Lipsius, "Estimating Available Water Capacity from Basic Soil Physical Properties: A Comparison of Common Pedotransfer Functions," M.S. Thesis, Braunschweig Technical University, Braunschweig, 2002, p. 38.

[11] K. R. Tiwari, B. K. Sitaula, R. M. Bajracharya and T. Borresen, "Effects of Soil and Crop Management Practices on Yields, Income and Nutrients Losses from Upland Farming Systems in the Middle Mountains Region of Nepal," Nutrient Cycling in Agroecosystems, Vol. 86, No. 2, 2010, pp. 241-253. doi:10.1007/s10705-009-9289-0

[12] SAS Institute, "SAS Version 9. 1.2 C2002-2003," SAS Institute, Inc., Cary, 2003.

[13] P. Hazeltonan and B. Murphy, "Interpreting Soil Test Results, What Do All the Numbers Mean?" Csiro Publishing, Oxford, 2007, p. 149. 
[14] T. Thamaraiselvi, S. Brindha, N. S. Kaviyarasi, B. Annadurai and S. K. Gangwar, "Effect of Organic Amendments on the Bio Chemical Transformations under Different Soil Conditions," International Journal of Advanced Biological Research, Vol. 2, No. 1, 2012, pp. 171-173.

[15] T. Aziz, S. Ullah, A. Sattar, M. Nasim, M. Farooq and M. M. Khan, "Nutrient Availability and Maize (Zea mays) Growth in Soil Amended with Organic Manures," International Journal of Agriculture and Biology, Vol. 12, No. 4, 2010, pp. 621-624.

[16] M. E. Ali, M. R. Islam and M. Jahiruddin, "Effect of Integrated Use of Organic Manures with Chemical Fertilizers in the Rice-Rice Cropping System and Its Impact on Soil Health," Bangladesh Journal of Agricultural Research, Vol. 34, No. 1, 2009, pp. 81-90.

[17] M. Bodruzzaman, C. A. Meisner, M. A Sadat and M. I. Hossain, "Long-Term Effects of Applied Organic Manures and Inorganic Fertilizers on Yield and Soil Fertility in a Wheat-Rice Cropping Pattern," 19th World Congress of Soil Science, Soil Solutions for a Changing World, Brisbane, 1-6 August 2010

[18] H. Shirani, M. A. Hajabbas, M. Afyuni and A. Hemmat. "Effects of Farmyard Manure and Tillage Systems on Soil Physical Properties and Corn Yield in Central Iran," Soil and Tillage Research, Vol. 68, No. 2, 2002, pp. 101-108. doi:10.1016/S0167-1987(02)00110-1
[19] W. Bayu, N. F. G. Rethman, P. S. Hammes and G. Alemu. "Application of Farmyard Manure Improved the Chemical and Physical Properties of the Soil in a Semi-Arid Area in Ethiopia," Biological Agriculture and Horticulture, Vol. 24, No. 3, 2006, pp. 293-300. doi:10.1080/01448765.2006.9755027

[20] R. Bhatacharyya, S. Kundu, V. Prakash and H. S. Gupta, "Sustainability under Combined Application of Mineral and Organic Fertilizers in a Rain-Fed Soybean-Wheat System of the Indian Himalayas," European Journal of Agronomy, Vol. 28, No. 1, 2008, pp. 33-46. doi:10.1016/i.eja.2007.04.006

[21] A. Bot and J. Benites, "The Importance of Soil Organic Matter Key to Drought-Resistant Soil and Sustained Food and Production," FAO Soils Bulletin 80, Food and Agriculture Organization of the United Nations, Rome, 2005. p. 78 .

[22] V. P. Singh and R. K. Singh, "Rain-Fed Rice: A Sourcebook of Best Practices and Strategies in Eastern India," International Rice Research Institute, 2000, p. 292.

[23] A. T. Hossain, F. Rahman, P. K. Saha and A. R. M. Solaiman, "Effects of Different Aged Poultry Litter on the Yield and Nutrient Balance in Boro Rice Cultivation," Bangladesh Journal of Agricultural Research, Vol. 35, No. 3, 2010, pp. 497-505. doi:10.3329/bjar.v35i3.6456 